\title{
On the value of general pedagogy practice in teacher education: A proposal of teaching practice tasks
}

\author{
OLGA ALEKSANDROWSKA \\ JOANNA GILIS-SIEK
}

Received 9.07.2019,

received in revised form 6.09.2019,

accepted 12.09.2019.

\begin{abstract}
The aim of the present paper is to explore the value of general pedagogy practice in educating pre-service teachers of English. In the first part of the paper, the discussion begins with a brief overview of some key concepts related to the teaching profession, teacher education and teaching practice. The major functions of teaching practice, with specific focus on general pedagogy practice, are examined in the light of the Regulation by the Minister of Science and Higher Education of 17 January 2012 on Educational Standards in Preparation for the Teaching Profession (2012). Furthermore, selected models and concepts of organising teaching practice at different Polish teacher training institutions are outlined. The second part of the paper is devoted to presenting an organisational framework of the general pedagogy practice at the Institute of English and American Studies, Gdańsk University. A proposal of a series of teaching practice tasks is put forward along with suggested content of the portfolio documenting trainees' field experience. The paper closes with some recommendations for improving the quality of the university practicum programmes.
\end{abstract}




\title{
Keywords
}

teacher education, pedagogy practice, trainee, portfolio, tasks

\section{Rola praktyki psychologiczno-pedagogicznej w kształceniu przyszłych nauczycieli języka angielskiego - propozycja zadań praktycznych}

\begin{abstract}
Abstrakt
Celem niniejszego artykułu jest przyjrzenie się wartości istocie praktyki psychologiczno-pedagogicznej w kształceniu przyszłych nauczycieli języka angielskiego. W pierwszej części artykułu dyskusja rozpoczyna się krótkim przeglądem wybranych kluczowych pojęć związanych $z$ zawodem nauczyciela, kształceniem nauczycieli oraz praktyka pedagogiczna. Główne funkcje praktyk nauczycielskich, ze szczególnym uwzględnieniem praktyki psychologiczno-pedagogicznej, sa przeanalizowane w świetle Rozporzadzenia Ministra Nauki i Szkolnictwa Wyższego $z$ dnia 17 stycznia 2012 r. sprawie standardów edukacyjnych w przygotowaniu do zawodu nauczyciela. Ponadto, przedstawiono wybrane modele i koncepcje organizacji praktyki pedagogicznej w różnych polskich instytucjach kształcących nauczycieli. Druga część artykułu poświęcona jest przedstawieniu ram organizacyjnych praktyki psychologiczno-pedagogicznej w Instytucie Anglistyki i Amerykanistyki na Uniwersytecie Gdańskim. Przedstawiono propozycję szeregu zadań zwiazanych $z$ tym typem praktyki oraz sugestie dotyczące zawartości portfolio dokumentującego doświadczenia praktykantów. Artykuł kończy się zaleceniami dotyczącymi poprawy jakości programów praktyk uniwersyteckich.
\end{abstract}

\section{Słowa kluczowe}

kształcenie nauczycieli, praktyka psychologiczno-pedagogiczna, praktykant, portfolio, zadania 


\section{Introduction}

With a view to an all-encompassing role of education in human life, teacher education merits special attention from the state and society concerned with the quality of future life (DarlingHammond 2006). Teacher training institutions are responsible for introducing pre-service teachers' to the teaching profession during their teacher preparation programme and teaching practicum. Their goal is to equip the students - prospective teachers - with the suitable knowledge, skills, behaviors and attitudes to be able to successfully perform their role of teachers and educators at different types of schools. It can, however, be observed that due to the economic, social, educational, cultural, political and technological transformations taking place globally and the changing needs of society resulting from them, the proper preparation of trainee teachers ${ }^{1}$ for their profession is becoming an increasingly challenging task. Let us look now at some of the imposed demands and obligations with respect to the teaching profession.

In search of the profile of an ideal teacher, educators worldwide have been putting forward their ideas of what professional teaching means. One interesting example of a new understanding of teachers' professionalism is provided by Gołębniak (1998: 160-161), who believes that "readiness for action, reflectivity, romanticism and pragmatism" constitute the essential components. In this view, a professional teacher is perceived as an individual who willingly undergoes or initiates changes in the educational sphere, reflects upon his or her own actions, engages in creating authentic, emotional relations with another human being, and at the same time pursues to find effective solutions to the encountered problems. Teacher professionalism can also be exhibited by a person's

\footnotetext{
1 Trainee teachers are also referred to in the present paper as trainees, trainee teachers, teacher trainees, student teachers, pre-service teachers, prospective teachers and future teachers.
} 
wide subject knowledge, skills, qualifications, personal traits and attitudes. As observed by Zawadzka (2004), there has been a noticeable increase in the number and level of requirements related to the teacher's competences and attributes, which emphasises the specificity and increasing public awareness of the importance of the teacher's profession. Currently, teachers are perceived to have a transformative power to affect learners and whole communities and to act as "agents of social change" (Bourn 2016: 1). Not surprisingly, the expectations placed on the teaching profession are exceedingly high, including the promotion of socio-cultural values, innovation, individualisation, autonomy, collaboration as well as interdisciplinarity and interculturalism.

Such a situation implies an urgent need for universities educating future teachers to design high-quality curricula and to prepare trainee teachers to be responsive to the transformed educational contexts. Not only should the curriculum of teacher training institutions be modified and adjusted to the contemporary educational reality, but also the format of teaching practice ${ }^{2}$, being central to teacher education (Perry 2004). It, therefore, appears worthwhile re-examining different aspects of the student practicum in order to identify various areas for improvement and suggest ways for raising its effectiveness.

\section{Selected teacher-related issues}

Before the concept of the teaching practicum is discussed in greater detail, it is worth reviewing only the issues related to the teaching profession which are most relevant for the considerations in the subsequent parts of the paper. It is vital to remember that becoming a teacher is a dynamic and long-

2 The period of time spent by a trainee on practising teaching (by observing or conducting classes) and/or engaging in other educational activities that constitutes a requirement in teacher education curriculum will be referred throughout this paper as teaching practice, student/teaching practicum, field experience and internship. 
lasting process consisting of several developmental stages. In brief, a teaching career starts with the stage of reception, acquisition, exposure to new knowledge and skills and building one's own teaching competence. It is the beginning of shaping one's own teaching identity (Beltman et al. 2015). At a later stage, the trainee undertakes the initiative to develop through a series of trainings during which he or she acquires and then refines the pedagogical and methodological skills. The last stage describes the achievement of high-level teaching skills, ability to critically reflect on one's own actions and to create new suggestions. Trotter (1986), for instance, proposes the following five-stage model of teachers' development:

(1) the novice level (beginner teachers);

(2) the advanced novice level / competent level;

(3) the effective level;

(4) the expert level;

(5) the master level.

Zaborowski (1984) offers a different set of phases in the teacher's professional development:

(1) methodological patterns;

(2) critical reflection;

(3) self-knowledge and self-control;

(4) creativity.

The various suggested stages or phases found in the subject literature share the same feature - they all point to a gradual progression from a person overly reliant on experienced educators' ready-made teaching solutions to a highly professional, autonomous teacher, aware of own potential and ready for innovative educational activities. Undertaking the studies in a teacher training institution and completing the student practicum corresponds to the first phase in the outlined models, the period in which the prospective teacher launches his or her career. The teacher training programme along with 
its inherent component of the practicum can then be perceived as a vital starting point for the trainee on the path to mastery.

There exists a rich and well-established literature regarding the set of these desirable personal attributes and dispositions, competences, roles and attitudes of the teacher. For the purpose of the present paper, the characteristics pertaining directly to the contemporary foreign language teacher will be briefly reviewed. Different Polish educators have focused on the issue of the foreign language teacher's profile, for instance Wysocka (2003), Zawadzka (2004), Jodłowiec and Niżegorodcew (eds. 2007), Aleksandrowska (2015), Andrzejewska and Wawrzyniak-Śliwska (eds. 2017). A large body of literature describes the characteristics of an ideal foreign language teacher. For instance, Allen (1980 cited by Brown 2007: 489) states that the following elements define a good English language teacher:

competent preparation leading to a degree in English language teaching, a love of the English language, critical thinking, the persistent urge to upgrade oneself, self-subordination, readiness to go the extra mile, cultural adaptability, professional citizenship and a feeling of excitement about one's work.

Then, Brown (2007: 491) offers his own list of characteristics of a good language teacher, which he calls "a synthesis of several unpublished sources", with four categories distinguished, namely: technical knowledge, pedagogical skills, interpersonal skills and personal qualities. The features belonging to the last group include being well-organised, conscientious, dependable, flexible, reflective, inquisitive, ambitious and maintaining high ethical standards.

Apart from some personal traits, the list of competences required from the foreign language mentioned in the subject literature is also impressively long and comprises, among others: linguistic competence, communicative competence, psycho-pedagogical competence, methodological competence, moral/ethical competence, intercultural competence, organis- 
ational competence, innovative-creative competence and media-related competence (Zawadzka 2004). The multiplicity of roles a contemporary foreign language teacher is expected to perform in the classroom is also striking. Zawadzka (2004), for instance, suggests that he or she should act as: an expert, an educator, a cultural mediator, an organiser, a moderator, an advisor, an evaluator, an innovator a researcher and a reflective practitioner. The last mentioned role - that related to the teacher's ability of critical reflection as well as the whole idea of reflective teaching - has become a central feature of teacher education and professional development (Schön 1983; Wallace 1991; Richards and Lockhart 1996). Furthermore, it should be added that effective teaching goes far beyond a set of fixed types of personal characteristics, skills and roles and is characterised by a relatively high level of unpredictability and uniqueness. However, creating multiple opportunities for the teacher to develop a variety of competences undoubtedly contributes positively to the teaching process.

On a final note, as can be inferred from this short overview, the number of personal traits, competences and roles of the 21 st century foreign language teachers is impressively high and one may only wonder how to ensure their continuous development in the course of university education.

\section{The role of teaching practice in teacher education}

Student teachers obligatorily receive a substantial dose of preparation for the profession in the course of their university education, as regards the teaching of their first subject, psychology, pedagogy and didactics. However, regardless of how much knowledge of selected methodological, psychological, pedagogical and educational issues they acquire during classes and lectures, such theoretical foundations do not suffice to turn them into fully-fledged teachers. The student's theoretical knowledge gained at the university must be integrated and/or confronted with the practical (field) 
experience and hence the teaching practicum becomes a valuable opportunity for achieving this effect.

The issue of teaching practice within the framework of teacher education is well covered in the academic literature. Specialists representing various academic disciplines have explored the topic from different perspectives. A plethora of papers and studies can be found on the functions of the student practicum, its types, factors involved in student teaching, emotions accompanying its implementation, challenges and benefits accruing from it, tools to verify the effectiveness of teaching practice, trainee-mentor-academic supervisor relations as well as different concepts of organising practice in teacher training programmes. Some of these issues will be reviewed below.

Teaching practice is considered to be one of the most valuable components of initial teacher education (Hill and Brodin 2004). In scholarly debates it can be classified either as a form of experiential learning (Kolb 1984), field-based learning (Lonergan and Andresen 1988) or learning by doing (Schön 1987). Samujło (2011: 6) states in her report on the effectiveness of teaching practice programmes: the time spent by students at schools should serve the experience and skills development independently. Preparing for the role of a teacher should not be understood as an act of merely providing students with their mentors' experience but as a process of creating favourable conditions for student teachers' personal reflections on their own actions. It should be perceived as a developmental path during which trainees will use their knowledge to discover what knowledge and skills they need and how to gain them.

Multiple roles are assigned to the student practicum. For instance, according to Jakowicka (1991), out of the many roles (cognitive, educational, research, innovative and creative), the cognitive and educational functions should be given prominence in teacher preparation. Kuźma (2000) perceives the internship as the contribution of mainly adaptive, innovative and reflective character. The adaptive function consists in 
adapting the student to the role of a teacher through his or her participation in a variety of situations in the school environment, the innovative function means the trainee's ability to create, innovate, design own methods of work and research while the reflective ${ }^{3}$ function refers to the opportunity of a trainee to repeatedly rethink the undertaken actions and evaluate their effectiveness. Moreover, the teaching practicum affects the trainees' motivational sphere. From the study conducted by Derenowski (2015), it emerges that $78 \%$ surveyed students claim their decisions concerning the teaching career have been confirmed owing to the teaching practice, while $22 \%$ have realised the need to search for a different professional path. So, in the case of many students the field experience might exert a direct impact on their future career choices - either motivate them to pursue the teaching career or demotivate them due to their negative experiences during the internship.

Teaching practice can also function as a diagnostic tool (Richardson et al. 2018). The experience of direct contact with the pupils, the classroom and the school employees brings about the discovery of one's own strengths and weaknesses as a trainee. As a result, both student teachers and their mentors are able to identify the areas of teaching that have been accomplished successfully during the practice period and those still in need of some improvement.

Finally, while appreciating the existence of teaching practice as an indispensable component of teacher education, it is crucial not to overestimate the impact of teacher education on student teachers' preparedness for teaching. Some student

3 According to Schön (1983), who was inspired by the work of Dewey (1933), reflection is an essential component of professional knowledge and practice and, hence, it is essential to introduce reflective practice to the curricula in initial teacher education. Schön distinguishes two types of reflection, each characterised by a different purpose and character: as reflection-in-action (done immediately and simultaneously with the individual's actions) and reflection-on-action (generated after the action is completed). It is expected that teacher trainees will employ both these types during their practice as it might help them turn into reflective practitioners in the future. 
teachers or mentors might assume that "Teacher education is all about being "classroom ready" (Loughran 2015: 13) and expect that it will equip a trainee with tools to handle all types of school situations. It should be emphasised that, as Northfield and Gunstone (1997: 55) aptly put it, "teacher education is by definition incomplete". It implies that teachers' preparation spans over a lifetime and neither graduating from teacher studies nor completing one's teaching practice automatically equals producing an accomplished teacher. The student practicum then might be considered only as one of the vital factors facilitating the student's entry into the profession.

All in all, the above-mentioned perspectives on teaching practice, its complex challenges and potential benefits accentuate its multidimensionality and make the present authors' investigation into the value of general pedagogy practice even more justified.

\section{General pedagogy practice in the light of the Educational Standards in Preparation for the Teaching Profession}

Teacher education and teaching practice in Poland must be organised in compliance with the guidelines set out in the Regulation by the Minister of Science and Higher Education of 17 January 2012 on Educational Standards in Preparation for the Teaching Profession 4 (Journal of Laws 2012, pos. 131). The Regulation presents a three-module format of teacher education. Module 1 relates to the trainee's preparation in the substantive scope to teach the first subject in accordance with the description of learning outcomes for the particular field of study. Module 2 refers to the trainee's preparation in the areas of psychology and pedagogy. The module consists of the following components: (1) general psychological and pedagogical preparation - 90 hours; (2) psychological and pedagogical preparation to teach at a given educational stage or stages -

4 Hereinafter referred to as "the Regulation". 
60 hours; (3) psychological and pedagogical practice - 30 hours. Module 3 addresses the trainee's preparation in the didactic area. The components of this module are: (1) scientific basis of didactics - 30 hours; (2) didactics of the subject at a given educational stage - 90 hours and (3) didactic practice - 120 hours.

The teaching practicum occupies an important place in modules 2 and 3 as it comprises psychological, pedagogical and didactic preparation. It emphasises the role of complementary education involving the integration of theoretical content with practice, both in the sphere of psycho-pedagogical and didactic activities. It is expected that in module 2 , the student will receive general preparation in the field of psychology and pedagogy, needed at a given educational stage, through participation in classes. In addition, the goals, role and shape of the practice enabling the development of pupil's care, educational and didactic skills are defined. According to the Regulation (2012: 10), the major purpose of general pedagogy practice is: "to gather experience related to the development and developments of the acquired psychological and pedagogical knowledge with pedagogical reality in practical operation". It appears fitting now to examine an extract from the Regulation (2012: 10-11) below, in which the characteristics of general pedagogy practice are formulated:

\section{[...] Practice}

During the internship, care and educational skills are formed through:

$1 /$ getting acquainted with the specificity of a kindergarten, school or facility in which the practice is carried out, in particular getting to know the caring and educational tasks implemented by the school, the way of functioning and organization of work, employees, participants of pedagogical processes and documentation. 
2/ observations of:

a/ organised and spontaneous, formal and informal activities of groups of pupils,

b/ activities of individual students including pupils with special educational needs,

c/ interactions between an adult (teacher, educator) and a child as well as interactions between children and teenagers (at the same and different age),

d/ processes of interpersonal and social communication,

e/ actions taken by the school mentor,

f/ ways of integrating various activities (related to care and education, didactics and therapy),

g/ group dynamics, roles played by members of the group, behavior and attitudes of children and teenagers,

h/ actions taken by the school mentor to ensure safety and discipline in the group.

3/ cooperation with the mentor in:

a/ exercising care and supervision over the group in ensuring security,

b/ taking up educational activities resulting from existing situations,

c/ undertaking activities for learners with special educational needs,

d/ conducting organised educational activities.

4/ acting as a guardian-educator in particular:

a/ diagnosing group dynamics and a position of individuals in the group,

b/ getting to know pupils and their social status, needs, interests and skills, determining the level of developmental preliminary diagnosis of disorders and dysfunctions,

c/ independent conduct of care and educational activities,

d/ taking care of a group of pupils in the course of their spontaneous activities,

e/ planning and conducting educational classes (i.e. integrating activities and preventive actions) on the basis of self-developed scenarios, 
f/ animating group activity and cooperation of its participants, organising pupils' work in task groups,

$\mathrm{g} /$ undertaking individual work with pupils (including learners with special educational needs),

$\mathrm{h} /$ undertaking educational activities of an intervention nature in conflict situations, situations of security threat, violation of other people's rights or failure to comply with established rules,

i/ taking care of the group of pupils outside the kindergarten or school,

5/ analysis and interpretation of observed and experienced situations and pedagogical events including:

a/ keeping practice documentation,

b/ confronting the theoretical knowledge with practice,

c/ self-assessment (being able to see own strengths and weaknesses),

d/ assessment of the course of activities and the implementation of established aims,

e/ post-observation meetings with the mentor to discuss observed situations and conducted activities,

f/ discussing accumulated experience in a group of students at the university.

The 30-hour general pedagogy practice is a kind of prelude to a 120-hour didactic practice, during which student teachers are required to pursue their obligatory activities and make observations of this preliminary practice. As can be noticed from the earlier quoted extract from the Regulation, considerably high expectations are placed on trainees as regards the number and scope of activities to be carried out during the practicum, preferably under the supervision of an experienced school mentor. While on the internship, trainees must be provided with an opportunity to observe and participate in the school life in a newly assigned role - that of a teacher trainee. Apart from the contact with the school mentor, they are also expected to cooperate with the head teacher, other teachers and school employees as well as pupils. Ultimately, the student teacher should gain a profound understanding of the 
functioning of the school institution. In order to ensure the completion of these objectives and the provision of high quality teacher education, universities must offer well-prepared and sufficiently detailed internship programmes. This vital issue is to be explored in the subsequent section.

\section{Different models and concepts of organising general pedagogy practice in teacher education}

As Ure (2009: 13-13, 18-19) claims, four major philosophical models of teacher education programmes can be found in the subject literature on the design in higher education, namely the partnership or collaborative learning model, the reflective model, the academically taught or clinical model and the pedagogical content knowledge model. Each of these models presents a slightly different view of schooling and teacher education. For instance, in the partnership or collaborative learning communication, collaboration, negotiation between the university and the schools of the practicum are of crucial importance. The reflective model promotes the reflective approach to trainees' internship and ensures the reflective process engages different partners of the internship. In the academically taught or clinical model, it is proposed that the practicum is extended in order "to provide preservice teachers with time to analyse and evaluate student development and learning, and to develop more individualised approaches to teaching and intervention in student learning" (Ure 2009: 14). Finally, the pedagogical content knowledge model emphasises the need to strengthen the relation between subject matter and pedagogy to provide trainees with a solid knowledge base of content and pedagogical issues that will allow them to improve their teaching ability. It should be added that different teacher training institutions frequently adopt a hybrid of the abovementioned approaches to their pre-service programmes of the student internship.

Apart from the philosophical models of teacher professional learning that constitute frameworks for the pre-service 
teachers' programmes, teacher training institutions have developed practical procedures and instruments to manage the student practicum. The Polish institutions engaged in teacher education must all be based on the same document - the Regulation concerning the educational standards for teacher education (2012). Despite the same legal basis, various teacher training institutions have developed their programmes and proposals as regards the implementation of general pedagogy practice as well as didactic practice. The solutions differ in the choice and number of tasks for trainees, hourly allocation, duration, the way of documenting, as well as the criteria for assessing the trainee's internship. It might now be interesting to briefly examine several organisational solutions offered by selected Polish universities. The discussion will only be limited to the module of general pedagogy practice as this constitutes the main interest of the present paper.

Let us look at one interesting example of the pedagogy practice organised by the Faculty of Humanities of the Maria Curie-Skłodowska University in Lublin (Nowy program Praktyki Ogólnopedagogicznej nd.). Trainees of different humanistic majors (including English Philology) complete 36 hours of the continuous pedagogical practicum. During this period student teachers become acquainted with numerous aspects of schooling:

The official dimension of school functioning - duration: 2 hours Hidden dimension of everyday school life -2 hours

Organising the learning environment -3 hours

The teaching-learning process during the lesson -3 hours

School conditions of upbringing -2 hours

Teacher-pupil relations -2 hours

The role and tasks of the educator in organizing work with a class -8 hours

Pupils' self-government and organization of free time -2 hours

Safety and prevention at school -3 hours

Family - forms of family support -3 hours

Supporting pupils -6 hours 
Pre-service teachers are obliged to prepare written documentation of their practicum in the form of a portfolio, referring to a variety of mandatory and optional tasks. The portfolio should contain several written assignments, for instance, a written essay "The analysis of a situation causing disturbance in the class" (description of a pupil's disruptive behaviour - the teacher's reaction, effects of the intervention, own interpretation and evaluation of the teacher's response). In addition, the trainee is provide expected to submit a written characteristics of a selected school class and a protocol of the observed form period (led by a tutor) with the trainee's analysis and evaluation. The portfolio also includes the trainee's own lesson scenario of a form period which he or she has conducted during practice together with some assessment remarks. Apart from these obligatory writings, there are several optional tasks that the trainee can choose from. The student teacher's practicum is assessed on the basis of his or her commitment, the school mentor's opinion and the written contribution included in the portfolio.

Another model of general pedagogy practice has been implemented at Adam Mickiewicz University in Poznań. According to the regulations of general pedagogy practice (Praktyka psychologiczno-pedagogiczna [...] nd.), the duration of the internship is 30 hours, including 20 contact hours, 5 hours for students' own work to prepare the scenarios or tasks to be implemented during general pedagogy practice and 5 hours to prepare documentation (portfolio, notes, selfassessment) after completing the internship. As the main aim of this practice is to shape trainees' care and educational competences, students are obliged to assist their mentors (preferable a school pedagogue or a psychologist), and observe different types of educational lessons as well as plan and conduct a few educational lessons and activities. Student teachers together with their mentors (pedagogue or psychologist) decide which educational classes, activities they will participate in. 
The tasks for student teachers could be generally divided into three groups, among which the first group of tasks comprises activities in which trainees assist different school workers (educators, psychologists, teachers, etc.) in their work, observe different educational classes or activities (7 hours) and later construct a short report, in which they characterise the observed activities and finish each short report with their own reflections. The remaining two groups of activities focus on stimulating trainees' creativity and encouraging their individual practical work, for instance, by performing the role of an educator, planner and tutor leading the classes of educational character ( 3 hours). After each class the trainee is supposed to prepare a note with the evaluation of the course of independently carried out activities and the assessment of the achievement level of the assumed objectives. Three hours are given to student teachers' disposal to perform the role of an educator in a school lounge. To prepare and discuss together with their mentor educational activities and design scenarios for school events student teachers are assigned 8 hours of the practicum period. Within one hour students are obliged to prepare a kind of sociogram in which they will examine and analyse the structure of a class assembly. In addition, the trainee's self-assessment is required (5 hours) in which the trainee comments on his or her strengths and weaknesses in relation to the prospective role as a subject teacher and an educator. To verify the learning outcomes, student teachers are obliged to complete journals of student internship and prepare portfolios consisting of post-observation reports on observed educational activities together with trainees' own reflections (collecting information), scenarios of all lessons and activities conducted (practical task requiring reflection), description of a sociogram together with the analysis of a class assembly and self-assessment (practical task requiring analysis and diagnosis) and finally all the aids obtained or constructed by the trainees.

At this point of the discussion, it seems worth mentioning Pankowska's Report (2011) on the organisation and effective- 
ness of teaching practice at selected (30) Polish teacher training institutions, which offers an invaluable insight into various aspects of the practicum as realised by different universities, including its compliance with the educational standards, ways and content of documentation, the scope of duties of different stakeholders, relations between the academic supervisor, the school mentor and the student teacher. According to the Report, the tasks designed by the examined universities can be grouped according to 5 categories: (1) collecting information, (2) practical tasks focusing on cognitive activities (interpretation, assessment, reflection), (3) practical tasks requiring diagnosis, (4) practical tasks related to the trainee's methodological skills and (5) practical tasks with regard to psychosocial skills. The findings reveal that the majority of the tasks in the examined teaching practice programmes aim at developing didactic skills and allow for searching information about the school environment. The other types of tasks are of minor importance while tasks requiring trainees to develop their diagnostic and psychosocial skills are "avoided or treated marginally" (Report 2011: 45). Furthermore, the studies analysed in the Report suggest the most frequent ways of documenting the trainee's actions are: lesson plans (also scenarios of form periods), observation protocols, mini-essays, practical materials designed by the trainee, analyses of different educational situations, characteristics of selected age groups, projects, descriptions of school events, assessment sheets and reflections. Let us close the current discussion by quoting, paradoxically, the opening sentence of the recommendations related to the design of tasks during the trainees' internship (Report 2011: 48):

[t]he selection of tasks is of primary significance for the effectiveness of the teaching practice, both in relation to the established objectives (whether trainees are able to achieve them), preparation for the professional start (whether they will be adequate for the future tasks of the teacher) as well as regarding the trainees' commitment and attitude. 
It appears fitting to state that the choice and design of tasks for the internship might help to guide student teachers through their practice and highlight the most essential areas for development. The process of completing a series of specific tasks might also facilitate the student teacher's later reflection on the entire practicum. Therefore, selection of tasks must be done in a careful and well-planned manner. The subsequent section of the paper aims at developing this issue.

\section{A proposal of general pedagogy practice tasks at the Institute of English and American Studies, Gdańsk University}

As emerges from the discussion generated in the previous section, regardless of some differences in the organisation of general pedagogy practice at various Polish universities, it is possible to identify some common ground, that is the educational stakeholders' deep concern for the effective implementation of the current educational standards as indicated in the Regulation and for providing effective teacher education programmes. It also becomes evident the design and selection of tasks within the teaching practicum might exert a considerable impact on the success of the internship and also on the trainee's positive perception of the field experience. The current section aims to present the choice of tasks as designed by the team of academic supervisors of the practicum at the first-cycle studies of English Philology at Gdańsk University.

First-year English Philology students of teaching specialization (BA) at the University of Gdańsk are required to complete a 30-hour general pedagogy practice. The trainee's role is to observe different aspects of school, a variety of phenomena taking place in the school and assist the school mentor in his or her work. Therefore, it is implemented in cooperation with a mentor, i.e. a school tutor supervising the internship. It seems that the minimum number of 30 hours proposed for the implementation of general pedagogy practice suggested in the 
Regulation [...] allows for a rather limited understanding of the school's system of functioning; yet, as assumed, it enables student teachers to become acquainted with the basic knowledge of the school life in which they complete their practicum.

In order to maximize the effects achieved during the internship, appropriate procedures, institutional regulations and practice activities should be established. Given the five basic trainee activities outlined in the Regulation, i.e. 1) becoming familiar with the specificity of the kindergarten, school or institution, 2) observing, 3) cooperation with the internship supervisor, 4) acting as a guardian and an educator, 5) analysing and interpreting pedagogical situations and events, a number of pedagogical tasks have been designed for the trainee to perform at the school of internship.

Furthermore, it is expected that during the internship student teachers prepare documentation of their practicum in the form of a portfolio. The portfolio consists of a set of official documents signed by the head teacher, school mentor and academic supervisor, description of obligatory tasks to be performed during the internship and in compliance to the guidelines contained in the Regulation as well as the trainee's written reflections of the practice. Completion of each activity in the tasks is to be confirmed by the mentor with a signature next to the task name. The tasks, they are divided into two groups, the first of which concerns the documentation and work of various school bodies, and the second relates to the trainee's active participation in various school events. In addition to these two tasks, the internship documentation includes a compulsory section entitled "Reflections on your general pedagogy practice", which will be discussed in greater detail in the study.

Table 1 and Table 2 below present the two obligatory tasks outlined in the practice portfolio to be completed by the trainee as part of general pedagogy practice. 
Table 1

Description of Task 1

\section{TASK No 1}

During the internship the trainee is obliged to become acquainted with:

1. The organisation of the school as an institution providing both care and education

2. The way in which form teaching is planned and realised in the school

3. The role of a school pedagogue/school psychologist

4. Work in the school common room, library, dining hall, etc.

5. Organisation of extra-curricular activities

6. Planning and realisation of the class tutor' duties

7. School documentation (teaching plans, assessment documentation, school statute, school self-assessment system, school curricula)

8. Team-work in subject areas (e.g. the foreign languages teaching team)

9. Teaching aids and school and classroom equipment

It is expected that after completing the first obligatory task the trainee should be able to characterise a given school, describe its statutory tasks, organs and the equipment it has, characterise basic documents regulating school work and be able to keep school records. Furthermore, it is hoped that the student teacher will be able to define the tasks and competences of teachers and other school staff (including a pedagogue, psychologist, librarian, teacher of the community centre, etc.) and discuss the principles of their cooperation with various participants in the pedagogical process (including work in subject teams). Table 2 below outlines Task 2 and activities to be performed by the trainees. 
Table 2

Description of Task 2

\section{TASK No 2}

It is important that during the internship the trainee is involved in at least 7 of the activities given below:

1. School assembly

2. School celebration/party

3. Teacher-parent meeting

4. Subject teachers' meeting

5. Teacher duty hours

6. Extra lessons/extracurricular activities/special interest group

7. Working with the class tutor

8. Helping to organise a school competition

9. School trip/outing

10. Other (describe)

As can be inferred, the second obligatory task requires the trainee to actively participate in various school events and/or conduct classes of educational nature. The set of activities included in this task puts trainees in a specific school-based situation, allowing them to gain valuable practical experience, and reflect on their own actions. Task 2 contains 9 examples of activities that could be implemented during the internship, but it is also indicated that the student teacher can perform a task that is not included in the list. The decision to allow trainees to add a new pedagogical activity to the list stems from the academic supervisors' wish to promote student autonomy and grant students and their mentors the choice of tasks. According to the instructions, however, trainees should attend at least 7 school events of different type. The attendance is to be confirmed by the mentor's signature. Events such as the pre-service teachers' participation in the school assemblies, celebrations, compensatory classes, inter- 
est circles and his or her assistance in the preparation of school competitions aim at helping to familiarise trainees with selected elements of the school reality. They enable student teachers to recognise the developmental needs and abilities of pupils in a given age group (including the specificity of working with a learner with special educational needs), observe motivational techniques applied while working with pupils, and also provide them with an opportunity to develop their own methods of work. Trainees' (active or passive) participation in a form period (lesson devoted to educational matters, run by the class tutor), a teacher-parent meeting, a meeting of a subject team, a hallway duty or organizing a school trip might raise their awareness of the school's educational role and some preventive measures taken to ensure safety and maintain discipline among pupils.

Summing up, as regards the design of this part of the student practicum, both obligatory tasks have been composed in agreement with the abiding educational standards in teacher preparation. The tasks are differentiated and relate to various psychological and pedagogical aspects of schooling. Their number and choice has been planned to enable the student teacher to become familiar with the school staff, documentation and equipment as well as to help him or her to assist the mentor in planning and conducting various educational activities. It is expected that the proposed tasks will help to improve trainees' organisational and social competences, and will allow them to discover the methods of effective communication with students, parents and other pedagogical and non-pedagogical employees during classes and extracurricular activities.

\section{The reflection section of the student teacher's portfolio}

As mentioned in the previous section, the portfolio serves as a way of documenting the trainee's commitment to practice 
and his or her progress on the way to become an autonomous teacher. The subject literature abounds with papers and studies on the significance of introducing a portfolio as a tool for practising the skill of reflection in trainees and supporting their development as reflective practitioner (Wolf and Dietz 1998; Zeichner and Wray 2001). The form and content of the portfolio differs considerably at different institutions. As regards the portfolio used for the purpose of general pedagogy practice at our Institute, there are three major components. Apart from the earlier described two parts of the portfolio, i.e. documentation confirming the realisation of Task 1 and Task 2, the trainees are expected to complete the third section entitled "Reflections on your general pedagogy practice" (see Table 2), in which they write down their reflections on this part of their internship according to the outlined points.

\section{Table 3}

The reflection section of the portfolio of the trainee's general pedagogy practice

\section{REFLECTION ON YOUR GENERAL PEDAGOGY PRACTICE}

1) Give your impressions of the school, the staff and the learners.

2) From the procedures and activities you were involved in or observed:

a) describe three you were able to do with ease or enjoyed doing and give your reasons

b) describe three you found more problematic and give your reasons.

3) Select a number of areas from this part of your practice. Say what you feel you have learned from them and how this knowledge will be useful for you in the next part of your practice.

4) Other comments relating to this part of your practice that you would like to share 
The first part of this reflective exercise (designed by the team of university practicum coordinators) refers to the trainee's general impressions of the school where they completed their practice as well as of the teachers and pupils they met. In the second part, the trainees are asked to provide a comment about the obligatory tasks they consider to have been easy, enjoyable or difficult. The third part of the reflection encourages trainees to explore selected areas of the practicum and justify these aspects' contribution to trainees' development as future teachers. In the final part, the trainee is invited to submit any additional remarks related to the completed fieldexperience.

It is expected that trainees' reflections alongside their oral comments and school mentors' feedback might provide useful research material for analysis and the findings will help to identify the attitudes of student teachers of English to different areas of pedagogy practice, the level of their preparation for the profession, the mentors' opinions about the strengths and weaknesses and will indicate directions of future improvements. A description of a short qualitative study on the student teachers' reflections on their general pedagogy practice and their performance of the above-mentioned practicum tasks can be found in another paper in this issue of Beyond Philology. ${ }^{5}$

\section{Concluding remarks}

The paper offers considerations related to the profile of a contemporary foreign language teacher, required personal attributes and competences, and underscores the multifarious role of general pedagogy practice in trainees' initial teacher education. It is the authors' hope that the presented practical proposal of tasks to be completed by trainees during the internship will also be of interest to educational researchers and practitioners engaged in teacher education. Finally, the

5 The study is described in the paper entitled "Pre-service teachers' views on their general pedagogy practice: An analysis of trainees' reflections". 
paper aims to accentuate the need to systematically monitor the system of the internship at the teacher training institutions. It, therefore, appears warranted to conclude with some remarks concerned with enhancing the overall quality of the practicum component at teacher training institutions. Our recommendations are as follows:

- integrating the theoretical and practical components more closely (classes and lectures on pedagogy, psychology, methodology should be closely correlated);

- adapting the problems discussed in the classes during the realisation of the module of psycho-pedagogical education to the needs of teacher trainees;

- extending the required length of general pedagogical practice as the currently suggested period ( 30 hours) is far from sufficient; trainees' preparation needed to develop a number of educational competencies requires much more time than can be provided by such a short-term pedagogy practice;

- improving the quality of university-school partnership, cooperation of academic supervisors of internships with school mentors - for instance (through exchange visits, meetings, online communication, conferences and reports);

- facilitating an exchange of experiences and observations between trainees and mentors (through direct or online discussion, forums, conferences);

- organising a series of trainings, workshops, courses or optional classes for all parties involved in the practice - practicum coordinators at the university, school mentors and trainees, (e.g. for trainees - workshops on topics frequently identified by them as "difficult", such as class management, discipline problems, conflict situations, educational issues, elements of educational law, keeping school records; for academic practicum co-ordinators and school mentors - e.g. workshops on the art of mentoring or observation, teaching a reflective approach in education);

- introducing a series of reflective exercises necessitating more lengthy, analytical comments on the implementation of each of their practicum tasks (for example an analysis of critical incidents); 
- modifying the reporting system by requiring trainees to submit more detailed reports on their general practice;

- providing more frequent and systematic oral and written feedback on trainees' involvement or development of their competences;

- raising the prestige/value of GPP in general assessment of a student (for instance by assigning more ECTS points to trainees for this part of practice);

- collecting and using educational materials of different kind at the university library - records, films, books, magazines, professional literature on teaching practice at schools - as aids for the academic supervisors.

It seems imperative that frequent improvements are undertaken by teacher training institutions to revitalise teacher education through successful internships. This could only be achieved provided there exists active collaboration and a high level of commitment among different stakeholders involved in the organisation of trainees' teaching practice.

\section{References}

Aleksandrowska, Olga (2015). The Educational Potential of Texts of Culture in Teaching English to Senior Secondary School Students. Frankfurt am Main: Peter Lang.

Andrzejewska, Ewa, Magdalena Wawrzyniak-Śliwska (eds.) (2017). Nauczyciele języków obcych: Konteksty pracy - kształcenie - doskonalenie. Gdańsk: Wydawnictwo Uniwersytetu Gdańskiego.

Beltman, Susan, Christine Glass, Judith Dinham, Beryl Chalk, Bich Nguyen (2015). "Drawing identity: Beginning pre-service teachers' professional identities". Issues in Educational Research 25/3: 225-245. Available at <http://www.iier.org.au/iier25/belt man.html>. Accessed 20.05.2019.

Bourn, Douglas (2016). "Teachers as agents of social change". International Journal of Development Education and Global Learning 7. 10.18546/IJDEGL.07.3.05.

Brown, Douglas (2007). Teaching by Principles: An Interactive Approach to Language Pedagogy. New York: Pearson Education. 
Darling-Hammond, Linda (2006). "Constructing 21st-century teacher education". Journal of Teacher Education 57/3: 300-314. Available at <https://doi.org/10.1177/0022487105285962>. Accessed 27.06.2019.

Derenowski, Marek (2015). "Wpływ praktyk nauczycielskich na rozwój refleksyjności studentów filologii angielskiej oraz na ich dalsze decyzje zwiazane $z$ wyborem zawodu nauczyciela". Neofilolog 45/1: 27-41.

Dewey, John (1998) [1933]. How We Think: A Restatement of the Relation of Reflective Thinking to the Educative Process. Boston: Houghton Mifflin.

Gołębniak, Bogusława Dorota (1998). Zmiany edukacji nauczycieli: Wiedza - biegłość - refleksyjność. Torun - Poznań: Edytor.

Hill, Grant, Kristi L. Brodin (2004). "Physical education teachers perceptions of the adequacy of university course work in preparation for teaching". Physical Educator 61/2: 74-87.

Jakowicka, Maria (1991). "Funkcje praktyk pedagogicznych w procesie kształcenia nauczycieli”. In: Maria Jakowicka (ed.). Relacje między teoria i praktyka $w$ ksztakceniu nauczycieli. Zielona Góra: Wydawnictwo Wyższej Szkoły Pedagogicznej, 34-37.

Jodłowiec, Maria, Niżegorodcew Anna (eds.). (2007). Dydaktyka języków obcych na poczatku XXI wieku. Kraków: Wydawnictwo Uniwersytetu Jagiellońskiego.

Kolb, David A. (1984). Experiential Learning: Experience as the Source of Learning and Development. Englewood Cliffs, NJ: Prentice-Hall.

Kuźma, Józef (2002). "Refleksyjna i innowacyjna rola praktyk w procesie kształcenia nauczycieli”. In: Józef Kuźma, Ryszard Wroński (eds.). Kształcenie praktyczne przyszłych nauczycieli nowoczesnej szkoły. Kraków: Wydawnictwo Naukowe Akademii Pedagogicznej, 8-15.

Kuźma, Józef (2000). Nauczyciel przyszłej szkoły. Kraków: Wydawnictwo Akademii Pedagogicznej.

Lonergan, Noel, Lee Andresen (1988). "Field-based education: Some theoretical considerations". Higher Education Research \& Development 7/1: 63-77.

Northfield, Jeff, Richard Gunstone (1997). "Teacher education as a process of developing teacher knowledge". In: John Loughran, Tom Russel (eds.). Teaching about Teaching: Purpose, Passion and Pedagogy in Teacher Education. The Falmer Press, 48-57.

Nowy Program Praktyki Ogólnopedagogicznej (nd.). Projekt: „www. praktyki.wh.umcs" - Przygotowanie i realizacja nowego programu 
praktyk pedagogicznych na Wydziale Humanistycznym UMCS współfinansowany ze środków Unii Europejskiej w ramach Europejskiego Funduszu Społecznego Priorytet III, Poddziałanie 3.3.2 „Efektywny system kształcenia i doskonalenia nauczycieli”. Available at </phavi.portal.umcs.pl/at/attachments/2014/0522/113 634-programme-praktyki-ogolnopedagogicznej-poprawiony.pdf $>$. Accessed 3.06.2019.

Pankowska, Dorota (2011). Praktyczne przygotowanie do zawodu nauczyciela: Raport $z$ analizy programów praktyk pedagogicznych. Zamość: Officina Simondis, Wydawnictwo Państwowej Wyższej Szkoły Zawodowej im. Szymona Szymonowica w Zamościu. Available at <https://wyszukiwarka.efs.men.gov.pl/product/praktycz ne-przygotowanie-do-zawodu-nauczyciela-raport-z-analizy-programo w-praktyk-pedagogicznych/attachment/93>. Accessed 20.05.2019.

Pearson, Allan T. (1994). Nauczyciel: Teoria i praktyka $w$ ksztakceniu nauczycieli. Warszawa: Wydawnictwa Szkolne i Pedagogiczne.

Perry, Rosemary (2004). "Teaching practice for early childhood: A guide for students". Available at <http://www.routledge.com. catalogues./0418114838.pdf>. Accessed 13.06.2019.

Praktyka psychologiczno-pedagogiczna dla studentów filologii angielskiej dla studentów filologii angielskiej $w$ zakresie specjalności nauczycielskiej studia I stopnia (nd.). Uniwersytet im. Adama Mickiewicza w Poznaniu. Wydział Anglistyki. Available at <http:// wa.amu.edu.pl/wa/files/20140317_praktyki_1a_regulamin_prakt yk_dla_pedagog_szkolnego_praktyka_psych_ped.pdf $>$. Accessed 8.07.2019.

Program praktyki nauczycielskiej (pedagogicznej 30-godzinnej oraz 120-godzinnej dydaktycznej) w szkole podstawowej dla studentów studiów I stopnia przygotowujacych się do wykonywania zawodu nauczyciela (2012). Unpublished material. Gdańsk: Uniwersytet Gdański, Wydział Filologiczny, Instytut Anglistyki i Amerykanistyki.

Regulamin studenckich praktyk zawodowych na kierunku filologia, specjalność filologia angielska, specjalizacja nauczycielska $w$ Państwowej Wyższej Szkole Zawodowej im. Szymona Szymonowica $w$ Zamościu (nd.). Available at <http://pwszzamosc.pl/data/file_ attachment/2121-10filologia-angielska-nauczycielska-regulamin-pr aktyk.pdf $>$. Accessed 1.07.2019.

Regulation of the Minister of Science and Higher Education of 17 January 2012 on the Educational Standards in Preparation for the Teaching Profession. Journal of Laws 2012, item 131, as amended. 
Available at <http://www.bip.nauka.gov.pl/roz.rzadzenia/rozpo rzadzenie-ministra-nauki-i-szkolnictwa-wyzszego-w-sprawie-stand ard-ksztalcenia-przygotowujacego-on-onkonywania-zawodu-cieucz lala.html>. Accessed 28.05.2019.

Richards, C. Jack, Charles Lockhart (1996). Reflective Teaching in Second Language Classroom. Cambridge: Cambridge University Press.

Richardson, Tony, Beverly Dann, Christopher Dann, Shirley O'Neill (2018). Formative assessment practices for pre-service teacher practicum feedback: emerging research and opportunities. Hershey: IGI Global Disseminator of Knowledge.

Samujło, Małgorzata (2011). Jakość i efektywność programów praktyk pedagogicznych $w$ percepcji studentów specjalności nauczycielskiej i nauczycieli - opiekunów praktyk $w$ szkołach: Raport $z$ badań. Zamość: Officina Simondis, Wydawnictwo Państwowej Wyższej Szkoły Zawodowej im. Szymona Szymonowica w Zamościu. Available at <https://wyszukiwarka.efs.men.gov.pl/product/jakosc-iefektywnosc-programow-praktyk-pedagogicznych-w-percepcji-stu dentow-specjalnosci-nauczycielskiej-i-nauczycieli-opiekunow-prak tyk-w-szkolach-raport-z-badan/attachment/97>. Accessed 20.05. 2019.

Schön, Donald (1983). The Reflective Practitioner: How Professionals Think in Action. New York: Basic Books.

Schön, Donald (1987). "Educating the reflective practitioner: Toward a new design for teaching and learning in the professions". Available at <http://educ.queensu.ca/ russellt/howteach/schon 87.htm>. Accessed 21.06.2019.

Trotter, Robert (1986). "The mystery of mastery". Psychology Today 20/7: 32-38.

Ure, Christine, Australian Learning and Teaching Council (2009). Practicum Partnerships: Exploring Models of Practicum Organisation in Teacher Education for a Standards Based Profession: Final Report. Australian Learning and Teaching Council, Strawberry Hills, N.S.W. Available at <https://pdfs.semanticscholar.org/ 5cf9/6494f35db32f562fof73bcb0326cdebad966.pdf>. Accessed 28.06.2019.

Wallace, Michael J. (1991). Training Foreign Language Teachers: A Reflective Approach. Cambridge: Cambridge University Press.

Wolf, Kenneth, Mary Dietz (1998). "Teaching portfolios: purposes and possibilities". Teacher Education Quarterly 25/1: 9-22. 
Wysocka, Marzena (2003). Profesjonalizm w nauczaniu języków obcych. Katowice: Wydawnictwo Uniwersytetu Śląskiego.

Zaborowski, Zbigniew (1984). "Psychologiczne podstawy doradztwa". Nowa Szkoła 5: 202-206.

Zarzadzenie $\mathrm{nr}$ 100/2014 Rektora Uniwersytetu Wrocławskiego z dnia 13 sierpnia 2014 Available at <http://www.ifa.uni. wroc.pl/site_media/uploads/documents/praktyki/Nr\%20100_20 14\%20z\%20dnia\%2013.08.2014\%20r.\%20wpropw\%20zmiany\%20 do\%20zarz.\%20Nr\%201_2013.pdf>. Accessed 28.06.2019.

Zeichner, Ken, Susan Wray (2001). "The teaching portfolio in US teacher education programmes: what we know and what we need to know". Teaching and Teacher Education 17: 613-621.

Zawadzka, Elżbieta (2004). Nauczyciele języków obcych $w$ dobie przemian. Warszawa: Impuls.

Olga Aleksandrowska

ORCID iD: 0000-0002-3722-9568

Instytut Anglistyki i Amerykanistyki

Uniwersytet Gdański

ul. Wita Stwosza 51

80-952 Gdańsk

Poland

angoa@ug.edu.p1

Joanna Gilis-Siek

ORCID iD: 0000-00028620-544X

Instytut Anglistyki i Amerykanistyki

Uniwersytet Gdański

ul. Wita Stwosza 51

80-952 Gdańsk

Poland

joanna.gilis-siek@ug.edu.pl 